\section{Deaf, Hard-of-Hearing, and Hearing Signing Undergraduates' Attitudes toward Science in Inquiry-Based Biology Laboratory Classes}

\section{Cara Gormally*}

Department of Science, Technology, and Mathematics, Gallaudet University, Washington, DC 20002

\begin{abstract}
For science learning to be successful, students must develop attitudes toward support future engagement with challenging social issues related to science. This is especially important for increasing participation of students from underrepresented populations. This study investigated how participation in inquiry-based biology laboratory classes affected students' attitudes toward science, focusing on deaf, hard-of-hearing, and hearing signing students in bilingual learning environments (i.e., taught in American Sign Language and English). Analysis of reflection assignments and interviews revealed that the majority of students developed positive attitudes toward science and scientific attitudes after participating in inquiry-based biology laboratory classes. Attitudinal growth appears to be driven by student value of laboratory activities, repeated direct engagement with scientific inquiry, and peer collaboration. Students perceived that hands-on experimentation involving peer collaboration and a positive, welcoming learning environment were key features of inquiry-based laboratories, affording attitudinal growth. Students who did not perceive biology as useful for their majors, careers, or lives did not develop positive attitudes. Students highlighted the importance of the climate of the learning environment for encouraging student contribution and noted both the benefits and pitfalls of teamwork. Informed by students' characterizations of their learning experiences, recommendations are made for inquiry-based learning in college biology.
\end{abstract}

\section{INTRODUCTION}

The development of positive attitudes toward science is critical for successful science learning. Attitudes are learned predispositions, developed through years of science learning experiences (Koballa and Crawley, 1985). In fact, attitudes toward science are more closely tied to future engagement with science than skills or content knowledge (Koballa and Crawley, 1985; Feinstein et al., 2013). Thus, if students are to engage with challenging social issues related to science in their everyday lives, developing positive attitudes is essential. Also, more than $80 \%$ of all college students are non-science majors, so one science course may be their last (National Science Board, 2014; National Student Clearinghouse, 2015). More immediately, students' attitudes toward science can impact their learning. First, students' attitudes, developed from years of habitual patterns of participation, attitudes, and expectations, may affect how they approach science learning (Osborne et al., 2003; Semsar et al., 2011). Attitudes toward science are connected to students' "need to know" and their need to succeed in the classroom (Koballa and Crawley, 1985). Second, students' attitudes may affect how they make sense of the discipline (Osborne et al., 2003; Semsar et al., 2011). In addition, negative attitudes toward science can lead to underperformance (Schiefele et al., 1992).
Jeff Schinske, Monitoring Editor Submitted June 19, 2016; Revised October 18, 2016; Accepted October 20, 2016 CBE Life Sci Educ March 1, 2017 16:ar6 DOI:10.1187/cbe.16-06-0194

Statement of possible conflict of interest: The author codesigned the inquiry-based curriculum for the introductory biology laboratories discussed in this paper.

*Address correspondence to: Cara Gormally (cara.gormally@gallaudet.edu)

(c) 2017 C. Gormally. CBE-Life Sciences Education @ 2017 The American Society for Cell Biology. This article is distributed by The American Society for Cell Biology under license from the author(s). It is available to the public under an Attribution-Noncommercial-Share Alike 3.0 Unported Creative Commons License (http://creativecommons.org/licenses/ by-nc-sa/3.0).

"ASCB $®$ " and "The American Society for Cell Biology $\circledR^{\prime \prime}$ are registered trademarks of The American Society for Cell Biology. 
Attitudes toward science have been defined in many ways (Gardner, 1975; Koballa, 1988; Koballa and Crawley, 1985; Osborne et al., 2003; Nieswandt, 2005). Generally, attitudes are defined as a "predisposition to respond positively or negatively to things, people, places, or ideas" (Nieswandt, 2005). Attitudes toward science are distinct from students' self-efficacy or confidence with science (Osborne et al., 2003). Conceptions of attitudes toward science sometimes focus on measures of student satisfaction, for example, change in interest in course material, relevance of course material to long-term goals, seeing the course as stimulating and exciting, and course difficulty (Basey et al., 2008; Armbruster et al., 2009; Baseya and Francis, 2011). Still others define attitudes as interest in leisure science learning, interest in a science career, and the enjoyment of science learning (Fraser, 1981; Nieswandt, 2005).

This study is shaped by conceptions of attitudes as described by Osborne et al. (2003). Osborne and colleagues (2003) deconstruct attitudes into two categories: attitudes toward science and scientific attitudes. The former are defined as "feelings, beliefs, and values held about an object which may be the enterprise of science, school science, the impact of science on society, or scientists themselves" (Osborne et al., 2003, p. 6). On the other hand, scientific attitudes are defined as the skills or ways of thinking needed for scientific inquiry. Osborne et al. (2003, p. 6) describe these scientific attitudes more specifically as "a complex mixture of the longing to know and understand; a questioning approach to all statements; a search for data and their meaning; a demand for verification; a respect for logic; a consideration of the premises and a consideration of consequences." This study primarily focuses on understanding students' attitudes toward science but also explores students' development of scientific attitudes. Importantly, attitudes are "learned predispositions" (Koballa and Crawley, 1985), implying that attitudes grow and change over time as a result of science experiences.

In inquiry-based laboratory courses, students "engage in many of the same activities and thinking processes as scientists" (National Research Council [NRC], 2000). Students themselves develop research questions, collect data to evaluate hypotheses, formulate explanations using scientific understanding, and interpret and communicate their experimental findings (NRC, 2000; Weaver et al., 2008; Beck et al., 2014). Inquiry-based teaching practices place more responsibility for learning with learners; for example, students are responsible for decision making in experimentation (Gormally et al., 2011, 2016), which may increase students' interest in science (Partin and Haney, 2012). We know that students in inquiry-based laboratory courses improve their skills with the scientific process (Brickman et al., 2009), science literacy (Gehring and Eastman, 2008; Brickman et al., 2009), conceptual knowledge (Cox-Paulson et al., 2012), and reasoning (Beck and Blumer, 2012; Beck et al., 2014; Kalinowski et al., 2012). Additionally, a comparative study by Bilgin (2009) showed that students had more favorable attitudes toward inquiry-based learning when working in cooperative groups than when working alone. Research in $\mathrm{K}-12$ classroom environments demonstrates that students exhibit improved attitudes toward science after participation in inquiry-based learning (e.g., see Gibson and Chase, 2002, and references therein). However, we know less about how college students improve their attitudes toward science after participation in inquiry-based laboratory learning (Baseya and Francis,
2011) and which features of inquiry are important to students' attitudinal growth.

This study investigates how inquiry-based learning affects students' attitudes toward science and their scientific attitudes. This study focused on college students who are deaf and hard-of-hearing and use American Sign Language (ASL), with the inclusion of a smaller number of hearing students who are fluent in ASL. Evaluating educational interventions in different student populations and institutions is crucial to understanding whether results can be generalized across courses and institutions (NRC, 2012). This study is one of few to determine how and for whom inquiry-based learning works (but also see Beck and Blumer, 2012). This is the first study about inquiry-based learning to focus on deaf and hard-of-hearing college students, of whom there are an estimated 50,000 undergraduates (Walter, 2010; Lalley, 2011). This is important, since deaf and hard-of-hearing individuals are underrepresented in science, comprising $0.8 \%$ of undergraduates but only $0.13-0.18 \%$ of doctorates (Walter, 2010; National Science Foundation [NSF], 2009). Fewer than 50 deaf individuals receive doctorates annually in science, technology, engineering, and mathematics (STEM) (NSF, 2007, 2009). At Gallaudet University, the site of this study, only $5 \%$ of undergraduates are science majors. It is important to note that this study is not a comparative study of hearing students and deaf and hard-ofhearing students, but instead focuses on the cultural Deaf community. Because a predominant feature of Deaf culture is the use of ASL for face-to-face communication, the Deaf community also includes ASL-fluent hearing people, many of whom were raised by signing deaf parents.

This study investigated the following research questions: How does participation in inquiry-based biology laboratory classes impact scientific attitudes and attitudes toward science of non-science majors in the signing Deaf community? What features of inquiry learning do these students report as supporting improved attitudes toward science? I posited that students who valued laboratory activities would be more likely to report positive benefits of science learning.

\section{METHODS \\ Study Context}

The study was situated at Gallaudet University, a small, liberal arts university whose mission is to serve deaf and hard-of-hearing students. Undergraduate enrollment also includes a limited number of ASL-proficient hearing students, most of whom are majoring in ASL interpretation. At Gallaudet, classes are conducted entirely in ASL, without spoken English, and curricular materials are designed in ASL and written English. The university is one of only three bilingual higher education institutions in the United States. Gallaudet is the only fully bilingual fouryear university requiring faculty competency in two languages for tenure and promotion.

At most universities, the classroom environment is auditory oriented; in an ASL-English bilingual class, it is visually oriented (Mather, 1987; Erting, 1992). Although comparing the two modalities (ASL and English) was not the focus of this study, it may be helpful for readers without much experience with the Deaf community to appreciate a few contrasts to better understand the context of the study. Classroom spaces are designed around the philosophy of Deaf Space to promote a visually accessible learning environment (Bauman and Murray, 2009). 
Of particular importance for classroom pedagogy is the incorporation of Deaf Space principles to arrange student desks in a large circle rather than auditorium-style seating. This allows instructors and all students to visually connect with one another for seamless whole-class discussion (since a student's comment cannot be acknowledged if it is not seen by students or faculty). This seating arrangement supports the use of eye gaze, which is critically important for taking turns in discussions in a visual bilingual classroom, as it regulates which person is allowed to hold the floor and make a comment (Mather, 1987). Eye gaze is an important attention-getting strategy as well; deaf individuals in the classroom (both faculty and students) will instinctively monitor others' eye movements to assess the flow of conversation (Graham, 2015). For a visually oriented active-learning classroom, other teaching strategies become important. For example, instructors will flash the classroom lights to call for the class's attention during student group work or enlist the help of other students in getting the attention of inattentive students; in an auditory-oriented classroom, this could be achieved by the instructor simply using his or her voice.

\section{Biology Laboratory Classes}

The study focused on students enrolled in a nonmajors introductory biology laboratory class. The course has no prerequisites and is a requirement for some nonmajors. Course content focused on human biology, including the reproductive, immune, skeletal, and muscular systems. The laboratory class met once per week for 2 hours. Students were simultaneously enrolled in the lecture component of the course.

In Fall 2014, the laboratory course was taught using traditional didactic approaches (Table 1). The instructor gave a brief lecture about the day's laboratory activity. Then, students worked either independently or in groups to do an activity, following step-by-step instructions. Students' grades were based on laboratory tests about content covered in the laboratory class, attendance, a final presentation about one disease, a laboratory report, and homework assignments.

During Spring 2015 and Fall 2015, an inquiry-based curriculum was implemented (Table 1). This inquiry-based curriculum was designed to follow established standards for inquiry learning (NRC, 2000) and is similar in design to a long-established (nearly a decade) inquiry-based laboratory course at the University of Georgia (Brickman and Gormally, 2007; Brickman et al., 2009). While how to design an inquiry-based laboratory curriculum is not the focus of this study, I would point interested readers toward Beck et al.'s (2014) review of what we know about inquiry-based laboratories and references therein. Readers may also be interested in the tremendous wealth of resources offered by the Association for Biology Laboratory Education (www.ableweb.org) to support instructors interested in designing inquiry-based laboratory activities. In our laboratory classes, experiments were divided into 2- to 3 -week-long units. For each unit, students worked in groups to develop a research question related to the unit topic and design an experimental protocol to collect data to test their hypotheses during the first week. During the second week, students collected and analyzed data, and discussed their findings. For each unit, students wrote mini-laboratory reports, focusing on developing one part of the laboratory report (e.g., developing a good introduction or writing a clear methods section). Students' grades were based on prelaboratory homework, class participation, and laboratory reports.

\section{Study Participant Demographics}

During the first and last week of each semester, participants completed a demographic survey that included questions about their backgrounds, preferred methods of communication and identity, and experiences participating in lab class (Table 2). Demographics of interviewees, using their pseudonyms, are described in Table 3.

\section{Data Collection and Analysis}

Semistructured individual interviews were conducted at the end of each semester (Fall 2014, Spring 2015, and Fall 2015; Table 4). The primary focus of the interviews was to understand students' perspectives about their experiences in laboratory class and how their attitudes toward science were affected by laboratory experiences. To address this focus, interviews began with questions to understand students' prior science learning experiences, and explored the relevancy of laboratory learning to everyday life. Finally, interviews also sought to understand what it was like to be a student in an inquiry-based laboratory class, in order to reveal students' characterizations of core elements differentiating inquiry-based teaching from traditional didactic laboratory teaching approaches. Videotaped interviews, conducted in the interviewee's preferred language, lasted 30-45 minutes, and were translated into English when necessary.

I coded the translated interviews with this research question in mind: How does participation in an inquiry-based laboratory course impact students' attitudes toward science? The coding process involved iterative cycles. The first cycle involved descriptive coding, as well as in vivo coding to capture participants' voices (Corbin and Strauss, 2008; Saldaña, 2013). Then, codes were mapped, and comparative tables were created to analyze emerging themes (following Miles and Huberman, 1994). Tables were used to compare students' perspectives about science learning, both individually and collectively within each semester and across semesters, to explore and identify similarities and differences in students' experiences. Themes emerged from analysis of comparisons.

The reflection assignment was a homework assignment for which students received course credit. Students completed the prereflection assignment during the first week of the semester and the postreflection assignment during the final 2 weeks of the semester in Fall 2015. The pre- and postsemester reflection assignment prompts included open-ended questions about students' prior science learning experiences, what they hoped to learn from the class, descriptions of their experience in laboratory class, their understanding of the scientific research process, and their conceptions about who does science (Appendix A in the Supplemental Material). Prereflection responses were used to establish students' initial attitudes toward science and examine whether students valued and found benefit in prior science learning experiences. I used descriptive coding and in vivo coding to capture participants' voices (Corbin and Strauss, 2008; Saldaña, 2013). When appropriate, I counted code frequencies and calculated percentages to indicate representative responses. Additionally, chi-square tests were used to evaluate 
TABLE 1. Comparison of the traditional and inquiry-based laboratory curricula

\begin{tabular}{ll}
\hline & Traditional lab (Fall 2014) \\
\hline Class 1 & $\begin{array}{l}\text { Introduction to the scientific method } \\
\text { Students develop a question and testable hypothesis. }\end{array}$ \\
Class 2 & No class: online laboratory safety quiz \\
Class 3 & $\begin{array}{c}\text { Students design an experiment based on their question } \\
\text { and hypothesis developed in class } 1 .\end{array}$
\end{tabular}

Class 4 Students write group lab report based on classes 1 and 2 .

Class 5 Activity: vaccination simulation

Students follow directions to simulate the spread of a disease in a population with and without vaccination.

Class 6 Activity: ELISA (enzyme-linked immunosorbent assay) and HIV

Students follow directions to set up an ELISA for HIV testing.

Class 7 Activity: microscopy and cancer cells

Students compare cancer cells with normal cells under the microscope.

Class 8 Laboratory test

Class 9 Activity: sheep brain dissection

Students dissect sheep brains.

Class 10 Laboratory test

Activity: microscopy and muscle tissues

Students compare different muscle types using a microscope.

Class 11 Activity: microscopy of bone cells

Students compare different bone cell types using a microscope.

Class 12 Activity: fetal pig dissection Students dissect a fetal pig.

Class 13 Laboratory test

Activity: paternity test using gel electrophoresis Students learn about genetics using gel electrophoresis.

Class 14 Student presentations about a disease

Class 15 Student presentations about a disease
Inquiry-based lab (Spring 2015 and Fall 2015)

Introduction to the scientific process and scientific literature

Preassessments

Reproduction, part 1

Activity: students design experiments to test hypotheses about the pregnancy status of fake urine samples.

Reproduction, part 2

Activity: students collect and analyze data for experiment designed in class 2.

Reproduction, part 3

Activity: students discuss findings from class 3 and practice science writing (edit an abstract).

Immune system, part 1

Activity: students design a way to model the spread of a disease in a population to test hypotheses about vaccination.

Immune system, part 2

Activity: students model the spread of a disease and collect and analyze their data.

Immune system, part 3

Activity: students model the spread of a disease using an online game and practice science writing (edit a methods section).

Nervous system, part 1

Activity: students design an experiment to test hypotheses about working memory using the Simon game.

Nervous system, part 2

Activity: students collect and analyze data for the experiment designed in class 8.

Exercise, part 1

Activity: students design an experiment to test hypotheses about fast- and slow-twitch muscles.

Exercise, part 2

Activity: students collect and analyze data for the experiment designed in class 10 .

Exercise, part 3

Activity: students discuss findings from class 11 and practice science writing (edit results).

Genetics, part 1

Activity: students design an experiment to test hypotheses about genetic inheritance using Caenorhabditis elegans.

Genetics, part 2

Activity: students collect and analyze data for the experiment designed in class 13.

Genetics, part 3

Activity: students peer review their drafts of their lab reports about the genetics lab.

\section{Efforts to Ensure Study Credibility}

Numerous efforts were made to ensure study credibility. First, I drew on best practices to make this research study Deaffriendly, making surveys and interviews available in both ASL and English, following participants' language preferences (Singleton et al., 2015). Also as a hearing person who is a second-language learner of ASL, not a native user, I worked with a graduate research assistant whose first language was ASL to 
TABLE 2. All research participant demographics, including survey, reflections, and interviews ${ }^{\mathrm{a}}$

\begin{tabular}{|c|c|c|c|c|c|c|}
\hline \multirow[b]{2}{*}{ Respondents } & \multicolumn{2}{|c|}{ Fall 2014 Traditional } & \multicolumn{2}{|c|}{ Spring 2015 Inquiry } & \multicolumn{2}{|c|}{ Fall 2015 Inquiry } \\
\hline & $N$ & Percentage of total & $N$ & Percentage of total & $N$ & Percentage of tota \\
\hline Total & 7 & & 36 & & 21 & \\
\hline \multicolumn{7}{|l|}{ Gender } \\
\hline Female & 5 & 71.4 & 12 & 33.3 & 4 & 19.0 \\
\hline Male & 2 & 28.6 & 24 & 66.7 & 16 & 76.2 \\
\hline Transgender & 0 & 0 & 0 & 0 & 1 & 4.8 \\
\hline Prefer not to respond & 0 & 0 & 0 & 0 & 0 & 0 \\
\hline \multicolumn{7}{|l|}{ Race/ethnicity* } \\
\hline African American & 0 & 0 & 7 & 19.4 & 4 & 17.4 \\
\hline Hispanic or Latino/a & 0 & 0 & 5 & 13.9 & 1 & 4.8 \\
\hline Native American, Alaskan Native & 0 & 0 & 1 & 2.8 & 1 & 4.8 \\
\hline Native Hawaiian, Native Pacific Islander & 0 & 0 & 0 & 0 & 1 & 8.3 \\
\hline Asian & 0 & 0 & 0 & 0 & 0 & 0 \\
\hline White & 4 & 57.1 & 21 & 58.3 & 14 & 60.8 \\
\hline Multiracial & 2 & 28.6 & 2 & 5.6 & 0 & 0 \\
\hline International & 0 & 0 & 1 & 2.8 & 1 & 4.8 \\
\hline Prefer not to respond & 1 & 14.3 & 0 & 0 & 1 & 4.8 \\
\hline \multicolumn{7}{|l|}{ Self-identification } \\
\hline Deaf & 3 & 42.8 & 17 & 47.2 & 10 & 47.6 \\
\hline Hard-of-hearing & 2 & 28.6 & 14 & 40 & 3 & 14.3 \\
\hline Hearing & 2 & 28.6 & 5 & 13.9 & 8 & 38.1 \\
\hline \multicolumn{7}{|l|}{ Preferred communication* } \\
\hline American Sign Language & 6 & 80 & 27 & 80 & 14 & 66.7 \\
\hline Signed English & 0 & 8.3 & 3 & 8.3 & 8 & 4.8 \\
\hline Spoken English & 3 & 42.9 & 13 & 36.1 & 1 & 38.1 \\
\hline Other & 1 & 14.3 & 0 & 0 & 1 & 4.8 \\
\hline \multicolumn{7}{|l|}{ Year in school } \\
\hline Freshman & 2 & 28.6 & 20 & 55.6 & 3 & 14.3 \\
\hline Sophomore & 4 & 57.1 & 9 & 25.0 & 10 & 47.6 \\
\hline Junior & 1 & 14.3 & 6 & 16.7 & 8 & 38.1 \\
\hline Senior & 0 & 0 & 0 & 0 & 0 & 0 \\
\hline Fifth- or sixth-year student & 0 & 0 & 0 & 0 & 0 & 0 \\
\hline Other & 0 & 0 & 0 & 0 & 0 & 0 \\
\hline
\end{tabular}

${ }^{\mathrm{a}}$ Asterisks are used to indicate that the percentage does not sum to $100 \%$, because participants were permitted to select multiple options. In Fall 2014, student participants ranged from 19 to 25 years old, 21.4 years old on average. In Spring 2015, participants ranged from 18 to 32 years old, 19.9 years old on average. In Fall 2015 , participants ranged from 18 to 31 years old, 21.5 years old on average.

coconduct interviews and translations. The manuscript was shared with the interviewees to check their understandings with the conclusions, listen to their comments, and incorporate their feedback.

Another aspect of ensuring study credibility involved recognizing and reflecting on my own identity as a hearing person and how my understanding of that identity developed. This identity becomes salient for most hearing people only when they become "impaired" as they enter into the Deaf community without ASL fluency, thus experiencing a fragment of what it means to be Deaf in a hearing world. It is at this time that they acquire a new, distinctive self-identity as "not-Deaf," or hearing (Bauman, 2014). For me, this involved unpacking a new identity, as I became part of the Deaf community. Now, while I teach in a bilingual classroom and am familiar with teaching and learning strategies for deaf and hard-of-hearing learners, my perspective is always that of a hearing person, not a deaf person. Thus, I believe it is of the utmost importance that my perspective be informed by deaf individuals who have this lived experience that I do not. Three faculty colleagues generously offered their insights as deaf and hard-of-hearing individuals who have been learners and educators in mainstream and deaf classrooms.

\section{Institutional Review Board Approval}

The project was approved by the Gallaudet University Institutional Review Board (proposal 2520) after expedited review.

\section{RESULTS}

\section{Attitudes toward Science before Laboratory Class}

One semester (Fall 2015) of data from reflection assignments offered a glimpse into students' initial attitudes toward science before participating in the inquiry-based laboratory classes ( $N=21$ responses). More than half of the students $(n=12)$ reported taking high school science courses, and nearly a quarter $(n=5)$ had previous college science courses. Students 


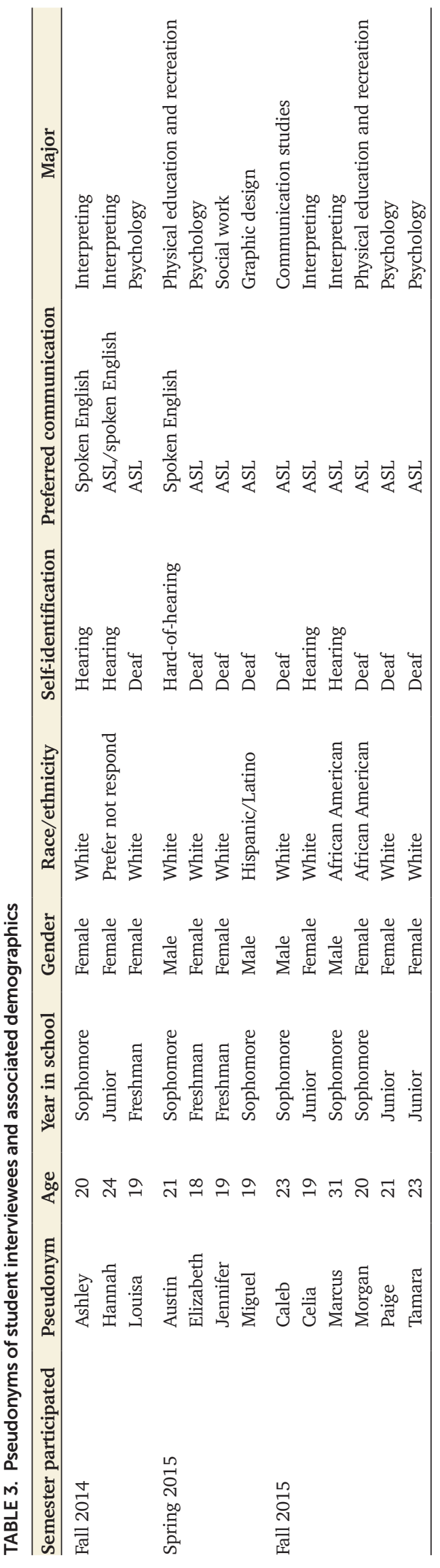

TABLE 4. Timeline of data collection ${ }^{\mathrm{a}}$

\begin{tabular}{lll}
\hline Semester & Presemester & Postsemester \\
\hline Fall 2014 & Demographic survey & $\begin{array}{l}\text { Demographic survey } \\
\text { Interviews }\end{array}$ \\
Spring 2015 & Demographic survey & $\begin{array}{l}\text { Demographic survey } \\
\text { Interviews }\end{array}$ \\
Fall 2015 & Demographic survey & Demographic survey \\
& Reflection assignment & Reflection assignment \\
& & Interviews \\
\hline
\end{tabular}

${ }^{a}$ Data were collected in Fall 2014, Spring 2015, and Fall 2015. Presemester data collection occurred in the first week of classes, while postsemester data collection occurred in the last 2 weeks of classes.

generally $(n=13)$ described their prior science learning experiences as positive; however, some students reported prior science learning experiences that were mixed (both positive and negative; $n=5$ ). The most frequent explanation provided was boredom due to the course design (e.g., students reported they wanted more hands-on activities and less lecture; $n=6$ ). More than half of the students $(n=12)$ reported that their prior science classes were beneficial to them: useful in other classes $(n=4)$, including their current biology laboratory, or in everyday life $(n=6)$. For example, one student explained that prior science learning was useful for writing laboratory reports in her current laboratory class. Another student stated,

Geology opened my eyes to what is really going on with the earth. It gave me the understanding to make better choices about the products that I use and where to purchase them. We can't hide from climate change anymore.

A small number of students $(n=2)$ noted that they struggled with biology previously or were worried about being successful in biology this semester. Yet as they faced a new opportunity to learn biology, students were generally positive. For example, one student wrote: "Biology and science was never my thing, but I hope taking this course will change that fact."

Analysis indicated that for two of the students (of five total) who had mixed learning experiences, their preexisting attitudes were influenced by the classroom environment they reported experiencing as a deaf individual and hard-of-hearing individual, respectively. In both cases, these students reported communication difficulties in the classroom. For deaf students in mainstream classrooms, equitable participation is often a challenge (Lang, 2002).

Reflection assignment data were not collected from students in traditional laboratories, so a comparison of presemester attitudes toward science was not possible.

\section{Attitudes toward Science after Laboratory Class}

Analysis of interview data from students who participated in traditional laboratory classes indicates that, for the most part, students had negative attitudes toward science at the end of the semester. One major theme emerged from analysis: students made few meaningful connections to laboratory learning. Students found little value in the laboratory activities. Two of the three interviewees repeatedly emphasized that during class, they often wondered, "Why are doing this [activity]?" For example, in response to the question, Ashley said, 
Every week, I thought some parts were pointless, paper activities or whatever. But other parts ... like ... really a few activities had equipment, you know? I remember the first day I had to set up 4 or 5 different cups and figure out which thing is inside which cup. So, that was interesting, to do something. Other days I felt like-paper worksheets-I'm just going through the motions of filling them out. It was easy. I felt like "why am I doing this?" I'm a big girl. I can study myself. I don't need something spoon-fed to me. You know?

Likewise, Hannah expressed that she sometimes felt the activities had no clear purpose:

[We were] pipetting samples. I remember that dragged on, the preparations. So I'm watching this, thinking, "Why? Taking a step back-why are we doing this?" It was never really explained. How is it connected? So what?

Knowing whether students value laboratory activities is important to understanding how participation in laboratory classes impacts their attitudes toward science. Additionally, understanding students' perspectives about the laboratory class work allows us to explore whether students perceive laboratory class activities as representative of the reality of doing science. In the traditional laboratory class, many activities were pencil-and-paper activities, in essence, forms with questions for students to answer, or step-bystep experiments with known, predetermined results. For these non-science majors, this did little to expose them to the realities of doing science. This suggests that traditional laboratory classes did not offer students alternative perspectives and learning experiences to challenge their learned predispositions about science. Students' negative attitudes toward science may have been reinforced by the traditional laboratory classes.

In contrast, analysis of interview and reflection assignment data from students in inquiry-based laboratory classes (Spring 2015 and Fall 2015) reveals a different story. In interviews, most students reported positive attitudes toward science as a result of participating in the laboratory. Additionally, chi-square tests were used to evaluate whether there were differences in the number of students reporting positive and negative comments about their laboratory experiences, based on student demographics. Results of the analysis of Fall 2015 postsemester reflection comments indicated there was no evidence of differences in responses to inquiry-based laboratory classes based on hearing status $\left(\chi^{2}(2, N=24)=8, p>0.918\right)$, gender $\left(\chi^{2}(1, N\right.$ $=23)=11.5, p>0.235)$, or race $\left(\chi^{2}(1, N=24)=12, p>0.404\right)$.

Three major themes emerged related to developing positive attitudes toward science (Feldman, 1988): 1) students perceived that "science applies to my life"; 2) students recognized "biology is not what I thought it was"; 3) students discovered that "I can successfully learn biology." The first theme emerging from analysis was students perceived that "science applies to my life." One interviewee, Jennifer, reported that her attitude changed when she realized that what she was learning applied to her life:

In the beginning (of the semester), I didn't like lab. I felt like, why? Then I realized, yes, it applies to real life, to daily life ... that's important information. If I need that information, this is a new opportunity to learn it ... I'm a social work major, so sometimes social workers have to do research, so I plan to use that to apply in my future. If something happens in the future
... if I'm curious about research-I can find information easier by using what I've learned from lab class. They're really transferable, too, when I'm in class, and I learn something new that's interesting, that applies to me, that applies to someone I know, or if something happens I can research it and help them out. Really, yeah, it applies to my life, my everyday life.

Similarly, Marcus described having a conversation with a coworker, sharing information about how genetics work, and recognizing how biology applied to his life. Both Jennifer and Elizabeth reported increased motivation to research their questions about science. Additionally, both Elizabeth and Tamara commented that they recognized how much they did not know and that they realized they use biology in everyday life.

A second theme was that students recognized "biology is not what I thought it was." In their reflection assignments, students wrote that their conceptions of the importance of research in biology had changed. Specifically, students described how their understanding of doing research changed due to their experiences of active engagement in designing and carrying out their own experiments. One student wrote,

At the beginning of the semester I thought that the scientific process was simple, quick, and easy. Now that I have actually had a taste of it, my perception is that it is an important, maybe even vital part of learning about life as we know it. Now I understand why we do it and I have a small experience of how [we do it].... [I]t's actually kind of fun to do it, even though it's not always easy.

Part of realizing that "biology is not what I thought it was" included realizing that biology could, in fact, be interesting. In her interview, Morgan described how her attitude toward science changed: "At first, I thought it was really boring. Then I realized, oh, I really enjoy this."

Finally, the third theme involved students discovering that "I can successfully learn biology." Some students discussed being unsuccessful in prior science learning experiences. Celia described that she began the semester with little confidence in her ability to learn biology. Through the course of the semester, she reported recognizing that

I can learn [science], I can teach myself about science. I'm not completely clueless about what science is and I can understand it.

Students described meaningful benefits from participation in the inquiry-based laboratory classes. In postsemester reflection assignments ( $N=17$ total responses), most students ( $n=$ 16) stated they expected to use what they learned in other contexts, an increase from the presemester reflection assignments. Students most frequently commented that they learned skills and biology content relevant to everyday life $(n=7)$ and to their careers $(n=6)$. Nearly one quarter of students $(n=4)$ commented that writing laboratory reports helped them to improve their writing skills. In his interview, Austin described the utility of learning how to find credible sources of information. He explained that he developed critical thinking-recognizing the need to investigate scientific claims to determine their validity-and described the need to seek out credible 
sources of information that were peer reviewed and unbiased. He also recognized that sometimes more research is needed to make a sound determination.

Perhaps most importantly, students from inquiry-based laboratory classes never expressed wondering "Why are we doing this?" In fact, students reported the opposite. In reflection assignments, students described seeing more connections with the laboratory activities. Experimentation was a common theme among students' comments. Repeated opportunities to engage with scientific inquiry themselves likely supported students to develop a more complex understanding of the nature of doing science. Nearly half of the students ( $n=7$ of 16 responses) described that research was more complex than what they previously understood. In her postsemester reflection assignment, one student wrote how her understanding changed:

My understanding of the scientific method has increased greatly. I now understand that it isn't just a bunch of numbers on a graph that I thought I would never understand. "Doing science" means questioning the things that we have around us. We challenge the things that were stated in the past.

Likewise, in interviews, students' explanations of what was involved in the scientific process were more nuanced (described more detailed below in Scientific Attitudes after Laboratory Class).

Yet in some cases, students' attitudes toward science did not change after participation in inquiry-based laboratory classes. Koballa and Crawley (1985) noted that attitudes are connected to a "need to know." A few students failed to develop this "need to know" biology or to see the role of science in their lives. For example, for Caleb, a transfer student who had already completed a science requirement at a community college, taking this laboratory course felt like taking a step back. He described feeling as though he had already "checked off that box" by completing his science requirement the first time. In his interview, he commented,

I'm not interested in science. It doesn't really apply [to my life]. Maybe if it's a really hot topic, I'd be interested in looking it up.

Caleb could not see the value of what he was learning. This might be due to his frustration from taking this required course. However, perhaps even more direct, explicit connections between laboratory activities and real-life activities are needed to further bolster existing discussions comparing laboratory experiments and everyday life. Additional emphasis of real-life connections may support students to develop this "need to know." For example, Paige described how she can now evaluate whether experimental findings are good quality. In theory, this is a skill she could apply when evaluating the quality of scientific information relevant to making decisions in her own life, for example, for health or environmental issues. However, she then said, "Honestly, after lab is finished ... it won't make a difference if I took it or not." While Paige recognized the value of this skill for writing laboratory reports, she could not envision applying this skill of evaluating scientific information for use in her everyday life. With explicit discussion of direct connections, students may identify ways they will use these skills in other contexts.

\section{Scientific Attitudes before Laboratory Class}

Analysis of the presemester reflection assignments suggest that most students in inquiry-based laboratories had few scientific attitudes at the beginning of the semester. When asked to describe what "doing science" meant to them, most students' written reflection assignments expressed naïve conceptions of doing science, including descriptions depicting traditional understandings of the scientific method as a specific step-bystep approach, involving the "right" method. One student's response is a representative example of the scientific method described as a specific step-by-step approach:

The scientific method is a process that allows scientists to often achieve authentic and successful results. It includes six steps: observe, question, hypothesize, experiment, create a conclusion, and report your results.

However, several students wrote more nuanced statements, suggesting they had begun to develop some scientific attitudes ( $n=5$ of 16). Most frequently, nuanced understandings included an explanation that doing science may involve making mistakes, as well as "critiquing and identifying mistakes"; a description of peer review as part of doing science; working as a team; and an explanation that scientific knowledge changes over time as scientists learn new information that results in changed conceptual understanding.

\section{Scientific Attitudes after Laboratory Class}

Data from interviews suggest that students in traditional laboratories developed few scientific attitudes by the end of the semester. Interviewees were asked, "Before you took lab, what was your understanding of the science research process? Now?" Students' explanations of the scientific process were very traditional, following an exacting, linear process. Analysis of interview data indicates that students did not develop scientific attitudes as result of participating in traditional laboratory classes. For example, students themselves often recognized that they were still confused about the scientific research process. More tellingly, students recalled few opportunities to actually practice the scientific process themselves in laboratory class. Thus, interview data indicated that few opportunities were available to develop scientific attitudes in these traditional laboratory classes.

Analysis of data from interviews and reflection assignments indicated that students in inquiry-based laboratories had many opportunities to develop scientific attitudes. In interviews, students' explanations of the scientific research process moved beyond naïve conceptions of an exacting step-by-step process. For example, students offered more complex understandings of scientific research, describing it as an iterative process. Interestingly, students sometimes described their understanding of the research process with a focus on communicating their experimental findings in their laboratory reports.

Three major themes emerged from analysis of interview data. First, students emphasized the importance of "preresearch planning and brainstorming." For example, Elizabeth, Austin, Louisa, and Tamara commented on the importance of doing background research to connect their own work to what was known. Students described using the literature to inform their experimental design and to interpret their results. Second, 
students described the need to really understand their data. Marcus explained that, even if an experiment failed, he could think about what his results meant. Both Austin and Paige discussed the importance of working to interpret the meaning of their data in order to provide enough depth to adequately communicate their findings in their laboratory reports. Austin stated: "Before I simply wrote down the data. That's it, I'm finished. I didn't research or review things." Third, collaboration and teamwork were essential components of the research process. In interviews and reflection assignments, students described how they experienced the process of doing science as they developed their own experiments with their groups. Tamara described how her vision of research changed in large part in response to working as group, so research felt "do-able":

I realized that working with a group really decreased the amount of work that we all needed to do. Each person contributes something.

Thus, students in inquiry-based laboratory classes were deeply engaged in doing scientific inquiry. Consequently, these students were exposed to opportunities to develop the scientific attitudes that are essential for scientific thinking and translatable to other aspects of life.

Students' reflection assignments described some of the scientific attitudes that they developed as result of participating in inquiry-based laboratory classes ( $N=17$ responses). Often, students described the kinds of scientific attitudes necessary for doing the scientific thinking and planning that is involved in doing scientific research. For example, students $(n=4)$ described developing skills to support working as a team. Other students $(n=4)$ described learning how to problem solve; the willingness to problem solve is another critical scientific attitude. Perhaps more interestingly, students were able to envision using these scientific attitudes in other scenarios. For example, students wrote about scientific attitudes that they developed, explaining the utility of these skills not only in the laboratory classroom but in their lives beyond the classroom:

"I learned patience because it takes time doing [an] experiment. Rushing things will not produce results. This is a skill that will be useful in my academic and workplace functions."

"We did a ton of work and experiments that engaged us as a class and we had to work with our classmates to achieve our goals. This was beneficial because in the real world we will interact with many other students, peers, bosses, colleagues, etc., and we need to know how to approach the situations when we have to work with these people."

"I learned how to work in a group and compare conclusions and ideas. I predict this skill will benefit me in a job environment, as I will most likely have to work with other people to solve problems and resolve issues. The group assignments ... greatly improved our peer review skills."

Notably, students not only recognized that they developed these scientific attitudes but also saw their value for work and life beyond their biology laboratory class.
Students also reported developing "people skills" as a result of extensive peer collaboration in the class. As one student explained, laboratory class required working as a team to develop their experiments. Through this experience, students reported realizing that they can learn from other students-not just the professor. Additionally, through peer collaboration, students learned how to communicate more effectively. In some cases, a lack of effective peer collaboration may have impacted students' attitudes toward science. In her interview, Paige noted that her group members were sometimes absent from laboratory class. As a result, she sometimes worked alone to develop and carry out experiments. She reported struggling through this process.

\section{Features of Inquiry-Based Laboratory Classes That Impact Attitudes}

Importantly, interview and reflection assignment data allowed for the identification of student-reported features of inquiry-based classrooms that impacted their attitudes toward science and scientific attitudes in both positive and negative ways. Questions focused on the "nature of the work" of learning in this environment in order to reveal students' characterizations of core elements of the learning environment.

Three major features of inquiry-based laboratory classes that impacted students' attitudes emerged from analysis (Feldman, 1988): 1) repeated engagement with hands-on student-driven experimentation encouraged students to develop positive attitudes; 2) peer collaboration "makes it or breaks it" when it comes to group work in the inquiry classroom; and 3) students felt supported by a positive classroom environment, which encouraged them to participate. Each of the three features of inquiry is described in more depth in the following paragraphs.

The first feature of inquiry identified by students was hands-on student-driven experimentation. Both Elizabeth and Miguel emphasized that hands-on student-driven experimentation was key to their learning. For them, experimentation was at the heart of their inquiry-based laboratory experience. Miguel also expressed that doing experiments helped him to connect his learning with what he had learned in lecture. In essence, the laboratory course reinforced and extended lecture learning. Likewise, students' repeated engagement with doing science themselves supported positive growth of scientific attitudes. For example, one student wrote in a reflection assignment:

I had a basic understanding of scientific research before this course because of the many science classes I have taken growing up. But, now this class focuses more on experiments and how to actually interpret the results and discuss what they mean and how they apply to the hypothesis. This class was more hands-on than my other biology classes, which helped me a lot more.

Students appreciated and enjoyed the hands-on, student-driven experimentation in the inquiry-based laboratory classes. In postsemester reflection assignments, students noted that experimentation was not only "fun and exciting" but that the inherent challenge involved was stimulating.

Students reported that peer collaboration was a major feature of inquiry learning. For students, peer collaboration either "makes [their experience] or breaks [their experience]" of 
learning in the inquiry-based laboratory classroom. Experimentation was tightly intertwined with working collaboratively with peers. In both interviews and reflection assignments, students described the process of working together to brainstorm ideas, develop and consider hypotheses to test, muddle through interpreting results, and then play with different ways to visualize their findings. Moments when students described feeling like scientists in the laboratory classroom reflected the fact that they were given ownership for this process, shared with their peers. For example, both Austin and Tamara described that they developed a sense that they could do this work, because their instructor gave them ownership for troubleshooting and problem-solving experiments themselves. The process of group collaboration supported students to take on inquiry for themselves.

Yet at times, students also reported features of inquiry-based learning that could be classified as pitfalls in inquiry-based teaching practices. In their postsemester reflection assignments, a few students $(n=2)$ noted that group work was occasionally a negative experience. One student explained "[I] figured out [experiments] with my group, which were positive experiences that I enjoyed," but noted "sometimes I felt that I did everything for [my group]." As discussed earlier, Paige reported similar feelings of feeling lost as she attempted to either work alone when group members were absent from class or feeling as though she had done a lot of work with little support from her group members.

Finally, students identified a third feature of inquiry learning: a positive classroom environment. Students described the inquiry-based learning environment as a "positive environment," which is important to support attitudinal growth. In the reflection assignments, one student explained "everyone in the room was welcoming and kind," and another wrote "I was always excited to come to this class." Moreover, when students described their positive experiences, these frequently involved working with peers and conducting experiments. One student wrote,

My positive experiences in lab would be group activities because it has improved my social skills greatly throughout the semester. I was put in the leadership position several times and I, for once, found it entertaining to be able to help other students.

In inquiry-based classrooms, students are expected to take on increased ownership for their learning and to develop their own understandings (Winter et al., 2001). Designing their own experiments places greater demands on students. Students must develop an adequate understanding of biology concepts to effectively apply these concepts to their experiments. For example, in their reflection assignments, some students reported times when they did not understand a concept and, consequently, were frustrated; they classified these moments as negative experiences in the laboratory class $(n=3)$. Yet these are moments that also offer possibilities for learning and growth. For example, one student described how his confusion about how to set up Punnett squares was resolved when both the professor and his classmates helped to explain the concept. In a moment such as this, students can come to see their classmates as supporting their learning and as legitimate sources of knowledge.

\section{DISCUSSION}

It is important for students to develop positive attitudes toward science, because their attitudes are closely tied to their future engagement with science (Koballa and Crawley, 1985; Feinstein et al., 2013). Often, non-science majors have few formal science learning opportunities at the university level. Yet the vast majority of U.S. students are non-science majors (National Science Board, 2014; National Student Clearinghouse, 2015). Thus, courses that promote the development of positive attitudes toward science are critical if students are to engage with challenging social issues related to science in their lives beyond the classroom.

We know that other evidence-based teaching approaches can lead to improved student attitudes at the undergraduate level (Armbruster et al., 2009; Harrison et al., 2011; Connell et al., 2016). This study sheds more light on how participation in inquiry-based learning can support undergraduate students' growth in attitudes toward science and science attitudes. In inquiry-based laboratory classes, students may develop positive attitudes toward science through the process of doing science themselves (but see Henige, 2011, for a discussion of how students may be more motivated by structure and clear objectives). This study demonstrated that students' learned predispositions are still malleable in college biology laboratory courses. Students in inquiry-based laboratory classes made positive growth in their attitudes toward science and scientific attitudes. Inquiry-based laboratory students reported benefits such as skills that applied to their lives beyond the laboratory classroom, including improved communication and teamwork, critical thinking, problem solving, and patience. University inquiry-based biology laboratory classes can foster the growth of positive attitudes toward science.

This is the first study to evaluate the implementation of inquiry-based biology laboratory learning for students who are deaf and hard-of-hearing. Literature emphasizes that "minds-on" learning strategies cognitively engage deaf learners, leading to enhanced achievement (Lang, 2006). At its core, inquiry-based learning is one type of minds-on learning. While learning gains in content knowledge and science process skills were not evaluated in this paper, importantly, inquiry-based laboratory experiences had a positive impact on these students' attitudes toward science and scientific attitudinal growth. Additionally, this study found no evidence of differences in responses about positive and negative attitudes toward inquiry-based laboratory classes based on hearing status, gender, or race. However, data indicate that two students' (one of whom was deaf and one of whom was hard-of-hearing) preexisting attitudes were influenced by their reported prior science classroom environments. Teaching and learning practices that make inquiry laboratory learning more equitable for deaf and hard-of-hearing students in mainstream classes are detailed later (see Strategies to Support Deaf and Hard-of-Hearing Students in Inquiry Laboratories).

Students also described features of the inquiry-based laboratory classes that positively affected their attitudes. Their characterizations of the inquiry-based laboratory environment align with published descriptions of elements of constructivist classrooms such as inquiry-based laboratories. Oh and Yager (2004) describe five key elements of constructivist classrooms: personal relevancy of the science to students' lives; student negotiation to justify and explain ideas to peers; shared control for learning 
with the instructor; critical voice (a classroom climate in which students feel comfortable questioning the instructor's pedagogical plan); and opportunities to experience how knowledge develops from scientific inquiry. According to students' characterizations as described in the Results, ongoing engagement with scientific inquiry was at the heart of the inquiry-based laboratory class. Moreover, this hands-on student-driven experimentation involved a high level of interaction with peers to collaboratively develop, trouble-shoot, conduct, and reach an understanding about their experiments. Peer interaction is a key element of inquiry-based, constructivist classrooms (Oh and Yager, 2004). Peer interaction is "how students explain and justify their ideas and listen and reflect on the viability of other students' ideas" (Oh and Yager, 2004, p. 107). Core elements that sustained the "work of the inquiry-based laboratory" included a Goldilocks level of challenge and a positive, welcoming, kind classroom environment in which students felt encouraged to contribute. Clearly, identifying the "sweet spot" of challenge-not too little and not too much-is key for keeping students engaged and only minimally frustrated, as others have noted (Henige, 2011). Research by Baseya and Francis (2011) supports this recommendation, as the authors report that students' perceptions of laboratory difficulty and time efficiency played a role in influencing students' attitudes. Creating a classroom environment that is warm and positive is conducive to supporting students as they delve into scientific inquiry (Gormally et al., 2016; Gormally, in press, 2017). Other work has revealed that there are positive correlations between attitudes and certain classroom characteristics, including learner-centered instructional design, high levels of personal support, and innovative learning activities (Osborne et al., 2003). Making learning relevant to students' lives should be a central goal for biology classes (Partin and Haney, 2012).

Student perspectives can also offer insights about misalignments between their experiences and faculty expectations in inquiry-based learning environments. From analysis of interview and reflection assignment data, two major potential pitfalls of inquiry-based learning were uncovered (Feldman, 1988). Students expressed that, at times, they felt frustrated 1) when they recognized their conceptual understanding was inaccurate or incomplete and 2) when they experienced the normal problems that can arise when working collaboratively with peers. It is clear from other research on students' attitudes toward science that both teachers and peers play a big role in influencing students' attitudes toward science (Koballa and Crawley, 1985). Consequently, effective instructor facilitation is essential to minimize student frustration as students take on more ownership for their learning (Gormally et al., 2016). Because we know that guiding students to build their conceptual understanding using constructivist teaching principles is challenging even for veteran inquiry instructors, it is important to continually exercise this skill (Crawford, 1999; Winter et al., 2001). Inquiry teachers must be cognizant of their role in facilitating group discussion and equitable participation, which in turn may reduce students' frustration with group work.

\section{STRATEGIES TO SUPPORT DEAF AND HARD-OF- HEARING STUDENTS IN INQUIRY LABORATORIES}

First, it is important to note that deaf and hard-of-hearing students in mainstream university classes have an experience in inquiry-based laboratory classes different from that of students in this study. In mainstream classes, deaf and hard-of-hearing students face many challenges to equitably participate with hearing peers (Lang, 2006). These factors include the pace of instruction or discussion, number of speakers, language and cultural differences, interpreters' familiarity with the content and signing style, and use of space (Lang, 2006), as well as lags and errors in real-time captioning and the technological limits of personal frequency modulation systems for cochlear implants and hearing aids. It is also important to emphasize that every deaf or hard-of-hearing student has individual preferences for accommodations; what works for one person is not necessarily the best strategy for another. Some strategies for faculty to better support their deaf and hard-of-hearing students in inquiry-based laboratories are discussed here.

While the content of our laboratory curriculum is similar to that of other universities, the delivery of the curriculum is designed with deaf and hard-of-hearing students in mind. Curricular materials (e.g., PowerPoints, handouts, laboratory manuals) include more visuals to show biological processes and relationships. For some deaf students, English is not their first language, and they are visual thinkers. As described in Methods, our classrooms are designed to minimize visual "noise" such as obstructions in sight lines and poor lighting.

Instructors should be aware that in interpreted conversations (ASL to English and English to ASL), the student is essentially relying on a third party - the interpreter - to provide access to information (Lang, 2002). This means there is little direct student-to-student or student-to-faculty communication (Lang, 2002). In interpretation, there is often a delay or lag, especially in large-group dialogues. Additionally, some things are lost in translation, not only idioms that exist in one language or culture, but more generally; we know that deaf students do not receive as much information from classroom lectures as hearing peers (Lang, 2002). The locations of the interpreter, the instructor or person speaking, instructional visuals (e.g., PowerPoint) can also lead to the division of visual attention, which presents a further challenge for deaf students and is exhausting over time (Solomon et al., 2013). Deaf students may be visually attending to spoken language, sign language, realtime text, and instructional visuals_-all at the same time. Thus, asking for input from your students about the location of these visual foci is critical. Additionally, for students, taking notes while watching these various visual foci is difficult; a note-taker may help to alleviate this issue (Solomon et al., 2013). Another challenge in interpreting is that there is a lack of a common sign language lexicon for scientific terms and training for interpreters in techniques that are appropriate for interpreting science classes (Solomon et al., 2013).

Group work is a key component in university inquiry-based laboratory courses. Instructors should work with all groups to facilitate effective group discussion and communication. Helping students to become aware of good communication strategies, such as turn taking, and occasionally pausing to be sure everyone is on the same page are part of an inquiry instructor's role to facilitate effective group work and communication. One strategy to promote better group communication may be to assign each student a role and responsibility within each group. For more strategies and ideas to better support deaf and hard-ofhearing students, I highly recommend my colleagues' excellent white paper, which is freely available (Solomon et al., 2013). 
"Deafness is a quality that exists between two people, not solely residing in one" (R. Nuzzo, personal communication). Although one person may be deaf and the other hearing, true communication is a two-way street that involves shared responsibility. Deaf people work hard to communicate with hearing people; diligent hearing people match that effort by recognizing their role and responsibility in dialogue. Hearing people have constant access to auditory cues and communication in nearly every environment. It is important to consider that deaf people are not disabled in communication when they are alone or in communication with other deaf people through written or signed language. It is only our environments that create disabilities. Good hearing instructors ask their deaf and hardof-hearing students to share what strategies work best for them, as different people have different preferences for accommodations (e.g., ASL interpreting, real-time captioning). Moreover, deaf students have a wealth of individual experiences living in a hearing world and can often provide valuable insights to what would better support their learning. Instructors in mainstream classes should be mindful of their role to create a learning environment that is accessible and encouraging for all students to learn.

\section{STUDY LIMITATIONS}

This study faced the challenges of recruitment and sampling inherent in working with a small population such as the Deaf community. During Fall 2014 and Spring 2015, I encountered challenges to recruiting students for interviews due to the small potential pool of study participants. During Fall 2015, I received grant funds, which included funds to compensate interviewees. Consequently, interviewees were compensated $\$ 20$ for their time during Fall 2015.

A second potential study limitation is that findings of shifts in attitudes may be limited, as interview data were collected in only two of the three semesters. Results are from end-ofsemester data only, rather than from both pre- and postsemester. It is possible that attitudinal changes might be either larger or smaller, if presemester data had been collected. The study design was enhanced by the addition of another data source in Fall 2015. This data source, the reflection assignment, was implemented in Fall 2015 to minimize the impact of small sample size as a study limitation. However, the Fall 2015 data were similar to those from previous semesters, so it is reasonable to think that attitudinal changes were captured appropriately with interview data during the other two semesters. Additionally, interview data are a preferred approach in qualitative methodology (vs. written survey data, such as the reflection assignment). Interviews are a powerful methodological tool for researchers. Using interviews allows researchers deep insights to participants' ways of thinking, reasoning, and worldviews, while offering researchers the opportunity to ask for further explanation and clarification (Patton, 2002). Given the nature of the research question and the small study population, qualitative approaches such as interviewing and surveys were appropriate methodological choices (Patton, 2002).

Another potential study limitation was that fewer data were collected during Fall 2014. As a result, comparative interpretations of traditional and inquiry-based laboratory data are limited. However, this study was designed to focus primarily on the inquiry-based laboratory classes, rather than as a comparative study.
More research is needed to understand whether undergraduates' attitudes toward science are persistent and stable over longer time periods. More research is needed to address questions such as Do students' end-of-semester improved attitudes represent a long-term change? Do students' more favorable attitudes toward science persist past graduation? Do students' attitudes remain more aligned with experts' attitudes? Can one positive formal science learning experience successfully "cancel out" students' prior negative attitudes? And, finally, how do students' improved attitudes translate to action in their lives (i.e., engagement with science in everyday life)?

\section{ACKNOWLEDGMENTS}

I thank the research participants for the opportunity to learn from their experiences in introductory inquiry-based biology laboratory classes in order to improve our teaching practices. I am grateful to Amber Marchut for her dedicated assistance in collecting and translating interview data. I thank Chris Beck for his feedback on a draft of the article. I also thank Amber Marchut, Caroline Solomon, and Regina Nuzzo for offering their insights and strategies to better support deaf and hard-ofhearing students. I acknowledge the support of an American Fellowship from the American Association of University Women to write this paper. The study also received support from the Gallaudet University Priority Research Fund. Finally, I acknowledge the precious gift of time and space to focus solely on writing this article, provided generously by a Playa Summer Lake Residency and the Gallaudet University Dean's Fund. All statements expressed in this article are those of the author.

\section{REFERENCES}

Armbruster P, Patel M, Johnson E, Weiss M (2009). Active learning and student-centered pedagogy improve student attitudes and performance in introductory biology. CBE Life Sci Educ 8, 203-213.

Basey J, Sackett L, Robinson N (2008). Optimal science lab design: impact of various components of lab design on students' attitudes toward lab. Int J Scholarsh Teach Learn 2, ar15.

Baseya JM, Francis CD (2011). Design of inquiry-oriented science labs: impacts on students' attitudes. Res Sci Technol Educ 29, 241-255.

Bauman H-DL (2014). On Becoming Hearing: Lessons in Limitations, Loss, and Respect (video file), TEDx Gallaudet. www.youtube.com/watch?v =yCuNYGk3oj8 (accessed 10 October 2016).

Bauman H-DL, Murray JM (2009). Reframing: from hearing loss to deaf gain Deaf Stud Digital J 1, 1-10.

Beck CW, Blumer LS (2012). Inquiry-based ecology laboratory courses improve student confidence and scientific reasoning skills. Ecosphere 3, ar112.

Beck C, Butler A, Burke da Silva K (2014). Promoting inquiry-based teaching in laboratory courses: are we meeting the grade? CBE Life Sci Educ 13, 444-452.

Bilgin I (2009). The effects of guided inquiry instruction incorporating a cooperative learning approach on university students' achievement of acid and bases concepts and attitude toward guided inquiry development. Sci Res Essay 4, 1038-1046.

Brickman P., Gormally C. (2007). The creature from beneath: an inquiry genetics exercise for introductory non-science majors. In: Tested Studies for Laboratory Teaching, Vol. 28, ed. MA O'Donnell, Proceedings of the 28th Workshop/Conference of the Association for Biology Laboratory Education (ABLE), 118-144.

Brickman P, Gormally C, Armstrong N, Hallar B (2009). Effects of inquiry-based learning on students' science literacy skills and confidence. Int J Scholarsh Teach Learn 3, ar16. 
Connell GL, Donovan DA, Chambers TG (2016). Increasing the use of student-centered pedagogies from moderate to high improves student learning and attitudes about biology. CBE Life Sci Educ 15, ar3.

Corbin J, Strauss A (2008). Basics of Qualitative Research: Techniques and Procedures for Developing Grounded Theory, Thousand Oaks, CA: Sage.

Cox-Paulson EA, Grana TM, Harris MA, Batzli JM (2012). Studying human disease genes in Caenorhabditis elegans: a molecular genetics laboratory project. CBE Life Sci Educ 11, 165-179.

Crawford BA (1999). Is it realistic to expect a preservice teacher to create an inquiry-based classroom? J Sci Teach Educ 10, 175-194.

Erting C (1992). Deafness \& literacy: why can't Sam read? Sign Lang Stud 75 , 97-112.

Feinstein NW, Allen S, Jenkins E (2013). Outside the pipeline: reimagining science education for nonscientists. Science 340, 314-317.

Feldman KA (1988). Effective college teaching from the students' and faculty's view: matched or mismatched priorities? Res High Educ 28, 291-344.

Fraser BJ (1981). TOSRA: Test of Science Related Attitudes Handbook, Hawthorn: Australian Council for Educational Research Limited.

Gardner PL (1975). Attitudes to science. Stud Sci Educ 2, 1-41.

Gehring KM, Eastman DA (2008). Information fluency for undergraduate biology majors: applications of inquiry-based learning in a developmental biology course. CBE Life Sci Educ 7, 54-63.

Gibson HL, Chase C (2002). Longitudinal impact of an inquiry-based science program on middle school students' attitudes toward science. Sci Educ $86,693-705$

Gormally C (2017) Developing a teacher identity: TAs' perspectives on learning to teach science as inquiry. Int J Teach Learn High Educ 28, 176-192.

Gormally C, Brickman P, Hallar B, Armstrong N (2011). Lessons learned from developing and assessing an inquiry-based college science curriculum. J Coll Sci Teach 40, 26-32.

Gormally C, Subiño Sullivan C, Szeinbaum N (2016). Uncovering barriers to teaching assistants (TAs) enacting inquiry teaching: inconsistent facilitation techniques, student resistance, and reluctance to share control over learning with students. J Microbiol Biol Educ 17, 215-224.

Graham PJ (2015). Examining the need of attention strategies for academic development in deaf and hard of hearing children. J Educ Hum Dev 4, 16-21.

Harrison M, Dunbar D, Ratmansky L, Boyd K, Lopatto D (2011). Classroom-based science research at the introductory level: changes in career choices and attitudes. CBE Life Sci Educ 10, 279-286.

Henige $K$ (2011). Undergraduate student attitudes and perceptions toward low- and high-level inquiry exercise physiology teaching laboratory experiences. Adv Physiol Educ 35, 197-205.

Kalinowski ST, Andrews TM, Leonard MJ, Snodgrass M (2012). Are Africans Europeans, and Asians different "races"? A guided-inquiry lab for introducing undergraduate students to genetic diversity and preparing them to study natural selection. CBE Life Sci Educ 11, 142-151.

Koballa T (1988). Attitude and related concepts in science education. Sci Educ 72, 115-126

Koballa T, Crawley FE (1985). The influence of attitude on science teaching and learning. School Sci Math 85, 222-232.

Lalley P (2011). Elements of Successful Support and Access Services for STEM Students Who Are Deaf and Hard of Hearing, NSF Report for Award HRD-0927586, Rochester, NY: National Technical Institute of the Deaf.

Lang HG (2002). Higher education for deaf students: research priorities in the new millennium. J Deaf Stud Deaf Educ 7, 267-280.

Lang HG (2006). Teaching science to deaf learners. In: Deaf Learners: Developments in Curriculum and Instruction, ed. DF Moores and DS Martin, Washington, DC: Gallaudet University Press.
Mather SA (1987). Eye gaze and communication in a deaf classroom. Sign Lang Stud 54, 11-30

Miles MB, Huberman AM (1994). Qualitative Data Analysis: An Expanded Sourcebook, 2nd ed., Thousand Oaks, CA: Sage.

National Research Council (NRC) (2000). Inquiry and the National Science Education Standards: A Guide for Teaching and Learning, Washington, DC: National Academies Press.

NRC (2012). Discipline-Based Education Research: Understanding and Improving Learning in Undergraduate Science and Engineering, Washington, DC: National Academies Press.

National Science Board (2014). Science and Engineering Indicators 2014 (NSF 14-01), Arlington, VA: National Science Foundation.

National Science Foundation [NSF] NSFDoSRS (2007). Women, Minorities, and Persons with Disabilities in Science and Engineering: 2007, Arlington, VA.

NSF NSFDoSRS (2009). Women, Minorities, and Persons with Disabilities in Science and Engineering: 2009, Arlington, VA.

National Student Clearinghouse (2015). Snapshot Report: Degree Attainment https://nscresearchcenter.org/snapshotreport-degreeattainment15 (accessed 16 May 2016)

Nieswandt M (2005). Attitudes toward science: a review of the field. In: Beyond Cartesian Dualism: Encountering Affect in the Teaching and Learning of Science, ed. S Alsop, Dordrecht, Netherlands: Springer.

Oh PS, Yager RE (2004). Development of constructivist science classrooms and changes in student attitudes toward science learning. Sci Educ Int 15 105-113.

Osborne J, Simon S, Collins S (2003). Attitudes towards science: a review of the literature and its implications. Int J Sci Educ 25, 1049-1079.

Partin ML, Haney JJ (2012). The CLEM model: path analysis of the mediating effects of attitudes and motivational beliefs on the relationship between perceived learning environment and course performance in an undergraduate non-major biology course. Learn Environ Res 15, 103-123.

Patton MQ (2002). Qualitative Research and Evaluation Methods, 3rd ed. Thousand Oaks, CA: Sage Publications.

Saldaña J (2013). The Coding Manual for Qualitative Researchers, Thousand Oaks, CA: Sage.

Schiefele U, Krapp A, Winteler A (1992). Interest as a predictor of academic achievement: a meta-analysis of research. In: The Role of Interest in Learning and Development, ed. KA Renninger, S Hidi, and A Krapp, Hillsdale, NJ: Erlbaum, 183-212.

Semsar K, Knight JK, Birol G, Smith MK (2011). The Colorado Learning Attitudes about Science Survey (CLASS) for use in biology. CBE Life Sci Educ $10,268-278$

Singleton JL, Martin A, Morgan G (2015). Ethics, deaf-friendly research, and good practice when studying sign languages. In: Research Methods in Sign Language Studies: A Practical Guide, ed. E Orfanidou, B Woll, and G Morgan, Malden, MA: John Wiley \& Sons, 7-20

Solomon CM, Braun D, Kushalnagar R, Ladner RE, Lundberg D, Painter R Nuzzo R (2013). Workshop for Emerging Deaf and Hard of Hearing Scientists: A White Paper, Washington, DC: Gallaudet University. http:// doit-prod.s.uw.edu/accesscomputing/sites/default/files/manual -upload/WhitePaper-Final_Gallaudet_Emerging_Sci_2_15_13.pdf (accessed 1 September 2016)

Walter GG (2010). Deaf and Hard-of-Hearing Students in Transition: Demographics with an Emphasis on STEM Education, Report for Testing the Concept of a Virtual Alliance for Deaf and Hard of Hearing STEM Students at the Postsecondary Level (NSF HRD-0927586) and Planning Grant for the Center for Advancing Technological Education for the Deaf (NSF DUE-0903167), Rochester, NY: National Technical Institute of the Deaf.

Weaver GC, Russell CB, Wink DJ (2008). Inquiry-based and research-based laboratory pedagogies in undergraduate science. Nat Chem Biol 4, 577-580.

Winter D, Lemons P, Bookman J, Hoese W (2001). Novice instructors and student-centered instruction: identifying and addressing obstacles to learning in the college science laboratory. J Sch Teach Learn 2, 15-42. 